\title{
Development of Environmentally Friendly Brake Lining Material
}

\author{
I K. Adi Atmika ${ }^{1, *}, I D G$. Ary Subagia ${ }^{1}, I W$. Surata ${ }^{1}$, and $I N$. Sutantra ${ }^{2}$ \\ ${ }^{1}$ Mechanical Engineering Departement, Udayana University, Bali-Indonesia \\ ${ }^{2}$ Mechanical Engineering Departement, Institut of Sepuluh Nopember, Surabaya-Indonesia
}

\begin{abstract}
Materials commonly used as brake pads are asbestos and alloys, but this material is very dangerous to the environment and health. This research was developed to answer these problems, namely to look for alternative brake pads that have good mechanical and structural properties and are environmentally friendly. Brake lining pads material is made from hybrid composite reinforced basalt, shells, alumina and bound using phenolic resin polymer (PR-51510i). This brake pads material is produced through a sintering process with an emphasis of $2000 \mathrm{~kg}$ for 30 minutes at a fixed temperature of $160^{\circ} \mathrm{C}$. This hybrid composite is made in as many as five variations, each of which is tested for wear resistance using a pin on disc test based on ASTM G 99-95a standards, while destilled water absorption test was based on ASTM D 570-98. The greatest wear rate is $0.000090 \mathrm{~g} / \mathrm{cm}$, which is still lower than wear rate of asbestos brake pad materials, and the highest destilled water absorption of the brake pads specimens obtained was 0.041558 still lower than the destilled water absorption of asbestos brake pads.
\end{abstract}

\section{Indroduction}

Brake lining pads is part of the braking system that immediately rubs against the rotating part. In general, brake pad material is made of asbestos material because its performance is still good to a temperature of $800^{\circ} \mathrm{C}$ [1], [2]. However, asbestos ingredients have been discontinued because they have carcinogenic properties that have a negative impact on the environment and human health [3], [4].

Then many researchers developed asbestos-free brake pad material. In 2014, Mgbemena et al developed the Palm kernel shell (PKS) based Pulverized non-asbestos friction material for reinforcing constituents, controlling friction imparting, elastomeric additives, fire retarding components and thermosetting resin. The results showed that the degradation temperature of the palm was obtained at $53.84 \mathrm{C}$ with a final degradation temperature of $634.87 \mathrm{C}$ and a percentage weight loss of $86 \%$.[5]. Then other researchers also developed shells based brake pads with a grit size of $600 \mu \mathrm{m}$. The material is tested still at speeds below $100 \mathrm{~km} / \mathrm{hr}$ [6]. Yawas et al. performed morphological tests of shellfish granules for friction plate material. The development of asbestos-free automotive brakes using periwinkle shell particles as frictional filler material is presented. This was with the characteristics of the periwinkle shell, which is mostly deposited as waste, in replacing asbestos which has been found to be carcinogenic [7], and the thermal test of the shellfish material for scraping material has also been carried out and has quite good properties [5]. But the results achieved at this time have not been able to maintain mechanical properties, especially against wear resistance and material performance at high temperatures.
This paper presents the characteristics of wear resistance and friction coefficient of brake pads material made from hybrid composite reinforced basalt, shells, alumina and bound using phenolic resin matrix polymer (PR-51510i). Basalt stone is one of the volcanic eruption materials that has heat resistance up to $1500^{\circ} \mathrm{C}$ [8], corrosion resistant, low water absorption and resistant to chemical treatment and non-toxic [9]. Basalt stone properties have excellent physical and mechanical properties, high tenacity, and high wear resistance [10], and can replace glass fiber [11]. Then the most important properties of this material are to have low thermal conductivity.

\section{Material and Method}

This research was carried out by hybridizing 3 types of material as reinforcement and one material as a matrix. The reinforcing materials are basalt powder, shellfish powder and alumina powder in the form of solid particles with a size of 60 mesh, then as a matrix material composite phenolic resin (PR-51510i) is used. Basalt properties are shown in table 1 . The shellfish powder material consists of $66.70 \% \mathrm{CaO}, 22.28 \% \mathrm{MgO}, 7.88 \%$ $\mathrm{SiO}_{2}, 1.25 \% \mathrm{Al}_{2} \mathrm{O}_{3}$ and $0.03 \% \mathrm{Fe}_{2} \mathrm{O}_{3}$. The process of making specimens is carried out by mixing reinforcing material and matrix material in the dry phase. Variations in the weight fraction of the brake pad material studied are shown in table 2.

The specimen formation process uses the sintering casting method at $160^{\circ} \mathrm{C}$, a pressure of 3 tons for 30 minutes. Testing of 5 specimen variations and 1 specimen from asbestos material was carried out by pin on disc

Corresponding author: tutadi2001@yahoo.com 
method based on ASTM G 99-95a standard (Figure 1 and Figure 2). Each specimen sample was given a load of 36 $\mathrm{N}$ taken in 83.3 minutes or 200 meters with an engine speed of $120 \mathrm{rpm}$ which resulted in friction on the surface of the sample. While the destilled water absorption test was based on ASTM D 570-98, then asbestos brake pads (X) is tested with the same method and standard.

Table 1. Mechanical properties of basalt material

\begin{tabular}{|l|l|}
\hline \multicolumn{1}{|c|}{ Properties of Basalt } & \multicolumn{1}{c|}{ Value (unity) } \\
\hline Density & $2600-2630\left(\mathrm{~kg} / \mathrm{m}^{3}\right)$ \\
\hline Tensile strength & $500 \mathrm{k}-550 \mathrm{k}(\mathrm{psi})$ \\
\hline Sintering Temperatur & $1050\left({ }^{\circ} \mathrm{C}\right)$ \\
\hline Operation Temperatur & $-265-+700\left({ }^{\circ} \mathrm{C}\right)$ \\
\hline Modulus of elastisitas & $9100-1100\left(\mathrm{~kg} / \mathrm{mm}^{3}\right)$ \\
\hline Melting point & $1170\left({ }^{\circ} \mathrm{C}\right)$ \\
\hline Heat resistance & $700-1000(\mathrm{deg} . \mathrm{C})$ \\
\hline Elongation at break & $3.15(\%)$ \\
\hline
\end{tabular}

Table 2. Weight fraction ratio of hybrid composite

\begin{tabular}{|c|c|c|c|c|}
\hline Composition & $\begin{array}{c}\text { Basalt } \\
\text { powder } \\
(\%)\end{array}$ & $\begin{array}{c}\text { Shellfish } \\
\text { powder } \\
(\%)\end{array}$ & $\begin{array}{c}\text { Alumina } \\
\text { powder } \\
(\%)\end{array}$ & $\begin{array}{c}\text { Phenolic } \\
\text { Resin } \\
(\%)\end{array}$ \\
\hline A & 45 & 5 & 10 & 40 \\
\hline B & 40 & 10 & 10 & 40 \\
\hline C & 35 & 15 & 10 & 40 \\
\hline D & 30 & 20 & 10 & 40 \\
\hline E & 25 & 25 & 10 & 40 \\
\hline
\end{tabular}

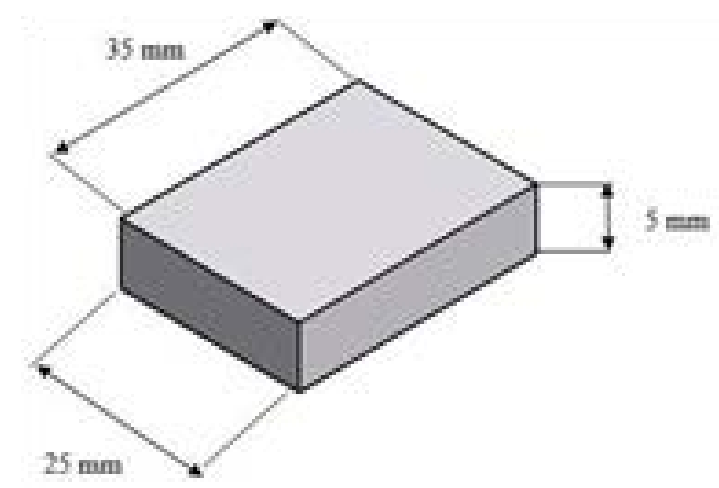

Fig. 1. Specimen geometry wear test

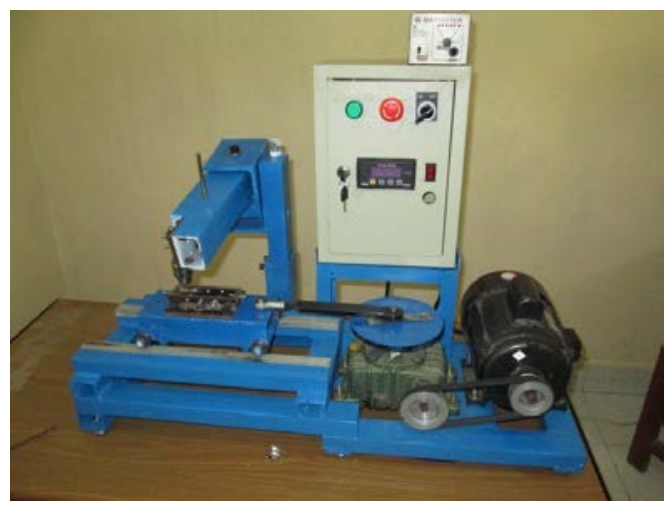

Fig.2. Pin on disc Equipment

\section{Result and Discussion}

The wear rate and friction coefficient $(\mu \mathrm{s})$ results are shown in table 3 . Then the comparison of wear rate for the five hybrid composite variations being developed and the asbestos $(\mathrm{X})$ brake lining pad materials is shown in Figure 3 and Figure 4. While the results of destilled water absorption tests are shown in table 4 . Then the destilled water absorption distribution of the five hybrid composite variations being developed compared to asbestos brake lining pads material $(\mathrm{X})$ are shown in Figure 5.

Table 3. Friction coefficients and wear rate values

\begin{tabular}{|c|c|c|}
\hline Composition & $\mu s$ & wear rate $(\mathrm{g} / \mathrm{cm})$ \\
\hline A & 0,410 & 0,000071 \\
\hline B & 0,402 & 0,000070 \\
\hline C & 0,398 & 0,000080 \\
\hline D & 0,370 & 0,000090 \\
\hline E & 0,360 & 0,000090 \\
\hline X & 0,330 & 0,000110 \\
\hline
\end{tabular}

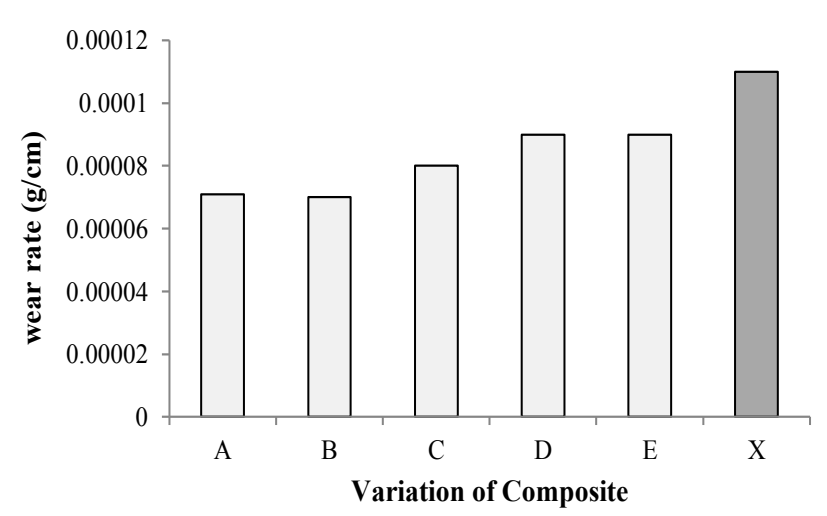

Fig.3. Wear rate of the hybrid composite and asbestos

Figure 3 shows a relationship diagram between variations in specimens with wear rate values, the lowest $0.000071 \mathrm{~g} / \mathrm{cm}$ and the highest is $0.00009 \mathrm{~g} / \mathrm{cm}$. The reduced amount of basalt content in specimens of wear 
rate value tends to be even greater, but still smaller than the wear rate value of asbestos brake pads specimens. So the five specimen variations of hybrid compsite brake pads have better wear rate value compared to asbestos brake pads.

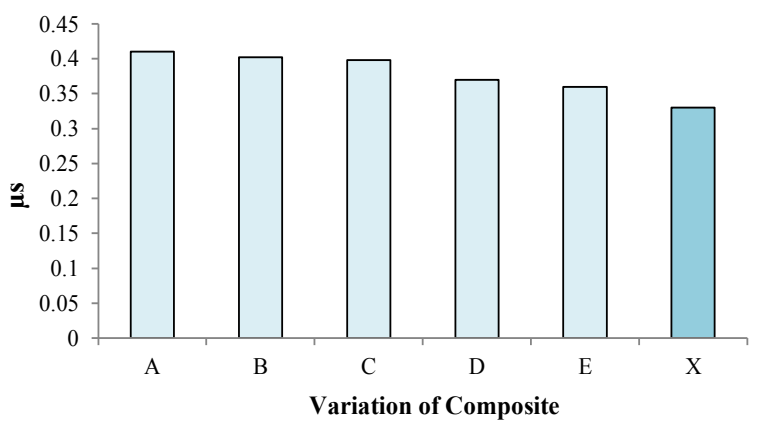

Fig.4. coefficient of friction from hybrid composite and asbestos

Figure 4 shows the average friction coefficient of hybrid composite brake pads for each composition variation. The friction coefficient value obtained thoroughly is higher than the friction coefficient value of asbestos brake pads. The difference in friction coefficient from hybrid composite brake pads is $9 \%$ to $25 \%$.

Table 4: destilled water absorption

\begin{tabular}{clllll}
\hline Variation of & \multicolumn{5}{c}{ destilled water absorption (\%) } \\
\cline { 2 - 6 } Composite & 3 days & 14 days & 24 days & 30 days & 60 days \\
\hline X & 0.032136 & 0.041588 & 0.043478 & 0.043478 & 0.043478 \\
A & 0.038961 & 0.041558 & 0.041558 & 0.041558 & 0.041558 \\
B & 0.031414 & 0.036649 & 0.036649 & 0.036649 & 0.036649 \\
C & 0.028721 & 0.033943 & 0.036554 & 0.036554 & 0.036554 \\
D & 0.026178 & 0.028796 & 0.031414 & 0.031414 & 0.031414 \\
E & 0.023499 & 0.026110 & 0.028721 & 0.028721 & 0.028721 \\
\hline
\end{tabular}

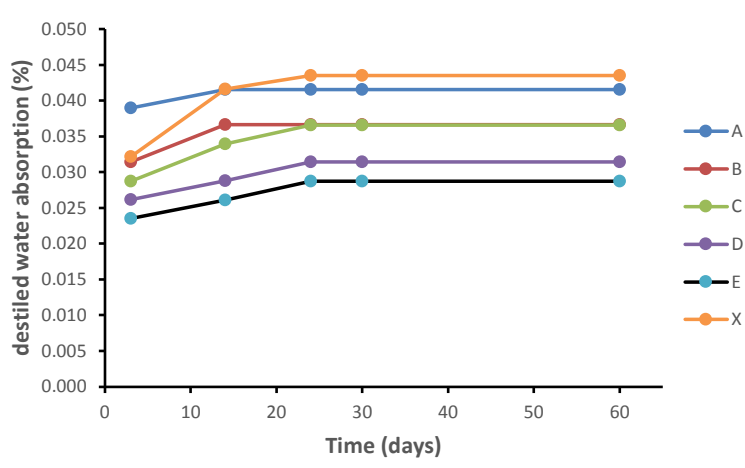

Fig.5. Destilled water absorption of the specimens

Figure 5 shows an overview of trends in destilled water absorption by hybrid composite materials being developed as well as asbestos brake pads material. It is seen that the trend after 24 days of immersion began to be constant for each specimen variation. The lowest destilled water absorption of specimens $\mathrm{E}$ was $0.028721 \%$ compared to the other four specimens and all of them were still below the destilled water absorption capacity of the asbestos brake pads material (X) [12].

Based on these results, basalt as the main reinforcing material from hybrid composite brake pads has had a quite effective effect on wear resistance, where with increasing basalt content the brake pads hardness also increases [13]. Furthermore, shellfish powder also affects the increase in friction coefficient that occurs in hybrid composite brake pads. While the alumina particles with a fixed amount due to the sintering temperature that has been carried out have not yet been achieved, it has not given a significant effect on the characteristics and friction coefficient value of composite hybrid brake pads (Figure 6).

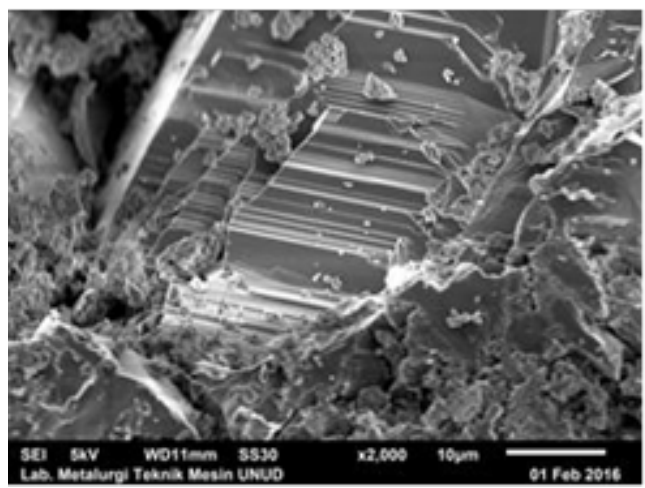

Fig.6. SEM photos of composites developed (2000x)

From Figure 6, observations of photography of alumina particles have not been bound by the composite matrix phenolic resin properly [14].

\section{Conclucions}

Reducing the percentage of basalt in each composition results in increased wear rate values, whereas the value of the coefficient of friction in each composition decreases. The wear rate value of the hybrid composite material is still smaller than the asbestos brake pad material, as well as the higher friction coeficient compared to the friction coefficient of the asbestos brake pad material. Furthermore the reduction in the percentage of basalt in each composition results in a decrease in destilled water absorption and is still lower than the absorption capacity of asbestos brake lining pads. So the hybrid composite material developed is very possible to replace asbestos material as an environmentally friendly brake pad materials.

\section{References}

1. M. A. Sivarao, M. S. Rizal, and A. Kamely, "An investigation toward development of economical brake lining wear alert system," Int. J. Eng. Technol. IJET, vol. 9, no. 9, pp. 251-256, 2009.

2. N. M. Kinkaid, O. M. O'Reilly, and P. Papadopoulos, "Automotive disc brake squeal," J. Sound Vib., vol. 267, no. 1, pp. 105-166, 2003.

3. M. G. Jacko, P. H. S. Tsang, and S. K. Rhee, "Automotive friction materials evolution during the past decade," Wear, vol. 100, no. 1-3, pp. 503-515, 1984. 
4. L. St, "US Survey shows imports of asbestos brake materials increasing," St. Louis, 2004.

5. C. O. Mgbemena, C. E. Mgbemena, and M. O. Okwu, "Thermal stability of pulverized palm kernel shell (PKS) based friction lining material locally developed from spent waste," ChemXpress, vol. 5, pp. 115-122, 2014.

6. P. C. Olele, A. C. Nkwocha, I. C. Ekeke, M. O. Ileagu, and E. O. Okeke, "Assessment of Palm Kernel Shell as Friction Material for Brake Pad Production," Int. J. Eng. Manag. Res., vol. 6, no. 1, pp. 281-284, 2016.

7. D. S. Yawas, S. Y. Aku, and S. G. Amaren, "Morphology and properties of periwinkle shell asbestos-free brake pad," J. King Saud Univ. Sci., vol. 28, no. 1, pp. 103-109, 2016.

8. V. Dhand, G. Mittal, K. Y. Rhee, S. J. Park, and D. Hui, "A short review on basalt fiber reinforced polymer composites," Compos. Part B Eng., vol. 73, no. December, pp. 166-180, 2015.

9. V. Fiore, G. Di Bella, and A. Valenza, "Glassbasalt/epoxy hybrid composites for marine applications," Mater. Des., vol. 32, no. 4, pp. 20912099, 2011.
10. A. A. Dalinkevich, K. Z. Gumargalieva, S. S. Marakhovsky, and A. V Soukhanov, "Modern basalt fibrous materials and basalt fiber-based polymeric composites," J. Nat. Fibers, vol. 6, no. 3, pp. 248 271, 2009.

11. V. Lopresto, C. Leone, and I. De Iorio, "Mechanical characterisation of basalt fibre reinforced plastic," Compos. Part B Eng., vol. 42, no. 4, pp. 717-723, 2011.

12. N. Venkateshwaran, A. ElayaPerumal, A. Alavudeen, and M. Thiruchitrambalam, "Mechanical and water absorption behaviour of banana/sisal reinforced hybrid composites," Mater. Des., vol. 32, no. 7, pp. 4017-4021, 2011.

13. R. D. Hyndman and M. J. Drury, "Physical properties of basalts, gabbros, and ultramafic rocks from DSDP Leg 37,” DSDP, vol. 37, pp. 395-401, 1977.

14. S. Choi and J. Kim, "Thermal conductivity of epoxy composites with a binary-particle system of aluminum oxide and aluminum nitride fillers," Compos. Part B Eng., vol. 51, pp. 140-147, 2013. 